\title{
Culture and Personality: A Examination of Impulsive Buying Behavior of Indian Consumers
}

\author{
Nishtha Bhushan, Bhawna Agarwal
}

\begin{abstract}
The leading objective of this paper is to unearth the influence of culture and personality of Indian consumers on their impulsive buying behaviour. A lot of research has been done to study the influence of external stimuli like advertisements and in-store promotions on consumers' buying behaviour. This paper studies the influence of internal stimuli on impulse buying behaviour. Impulse buying is an unplanned buying or accidental behaviour of consumers. This paper tries to establish a relationship between different personality traits and accidental behaviour of consumers. The impact of Big Five personality traits and culture (Individualism and Collectivism) on the impulsive buying behavior is studied. Data has been collected from consumers using structured questionnaire on a five-point Likert's scale. The data would be analysed through various statistical tools using SPSS.
\end{abstract}

Keywords: Impulse Buying Behavior, collectivism and individualism, personality

\section{INTRODUCTION}

The retail market in India has been growing very fast because of economic growth. India stands third only after China and Brazil in Net Retail Sales.India has reached an all-time high in terms of per capita availability of retail store. India's retail sector is experiencing an exponential growth. The dynamic and ever changing demographic profile, swelling disposable incomes, urbanization, varyingconsumer tastes and preferences have been driving the growth in the organized Indian retail markets. India is the fifth largest global destination in the retail space. According to "A T Kearney 2016, Global Retail Development Findings", GDP growth, ease of doing business, and better clarity regarding foreign direct investment (FDI) have put India in the second place in 2016 Global Retail Development Index.Indian retail market is anticipated to reach US \$1 trillion by 2020 essentially due to rise in income, urbanization and shifts in behavior of consumers. Retail demand has beenconsiderablymotivated by urbanization, an ever escalating middle class and more and more women entering the workforce.

Revised Manuscript Received on October 15, 2019.

Nishtha Bhushan, Phd Scholar, Amity College of Commerce and Finance, J1 Block, Second Floor, Amity University Campus, Sector 125, Noida 201313, India \&

Assistant Professor, Bharati College, Delhi University, Delhi, India

Dr. Bhawna Agarwal, Professor, Amity College of Commerce and Finance J1 Block, Second Floor, Amity University Campus, Sector 125, Noida 201313, India.
Engel et al (1978)explains unplanned purchasing for a purchasing action was accepted with no problem having been formerly beenacknowledged or a purchasing goal formed before entering the shop. Piron(1993)defines proposed buy as an specific opposite of unplanned buying andconceptualized planned buy for a purchasing action undertaken using a difficulty having beenformerly recognized or a purchasing intention formed before to entering the shop. In entirety, although all urge buys are bond purchases, however all fanatical purchases aren't allcreated on impulse. Piron suggests that all buys, if intended, unplanned or left on impulse could be experiential (i.e. accompanied by psychological and/or cognitive responses) or even non-experiential. Impulsebuying can be described as "a surprising and strong desire to purchase instantly" andhappens every time a customer purchases a product that the customer had no purpose ofbuying before going into the shop. Impulse buying could be prejudiced byoutside incitements like store attributes and purchase promotions,internal stimulation like pleasure and self-identity, Societal and merchandise related factorslike time and cash available, and demographic andsociological things like sex, age, and schooling.

The study achieved by Nielsen International indicates that roughly 72 percentof FMCG buys are projected, but $28 \%$ of grocery store imports are either unplanned or impulse buys. TheTop Rated unplanned purchases from the food class are sweets, chocolates, snacks, frozen desserts and snacks along with also the Top Rated unplanned buys in the non-food class aremakeup, air-fresheners,toothbrushes, soaps and hand/body creams.

Individualism and Collectivism

"Based on Lee and Kacen (2000), collectivist respondents were some what wealthier with theirurge buy as it had been created from the presence of a friend or a relative whereas individualist respondents wereboth pleased with their impulse buys if they left purchases either alone or with somebody. They reached the decision which civilization affects consumers' buying behaviours. 
According to Triandis (1994), each person takes both individualist and collectivist inclinations, the sole difference beingthat in certain civilizations, the probability of individualist attitudes, values and behaviours being present could be higher/ lower compared to others. In individualist cultures, most individuals are just worried about themselves or their immediate householdwhereas in collectivist cultures, individuals belong to classes and manage everyone around. They're worried about everybody connected together. They act as a team. Triandis (1995) described individualism as a societal arrangementcomprising those that are autonomous and independent whereas he described collectivism asa societal pattern comprising those who believe themselves as a substantial portion of classes, such as family or coworkers. Thesesocietal structures affect spontaneous purchasing behavior. India has an intermediate score of 48 (Geert Hofstede), thus, India is a society with both individualist and collectivist traits".

\section{Personality}

"Kollat and Willet (1967) examined the association between personality traits and impulsive buying behaviour but did not show any significant differences. Shahjehan et al.(2012) examined that consumers with anxiety, emotional instability, moodiness and sadness were more likely to be indulged in impulsive buying. The dimensions of personality traits developed by Sofi and Nika (2017) were used in this study, namely: expressive, emotional stability, sociableness, conscientiousness, pleasure seeking personality and conserving propensity. Verplanken and Herabadi (2001) revealed that the impulsive buying propensity is strongly entrenched in personality traits of a consumer".

The personality traits studied in this paper are:

* "Pleasure Seeking Personality:They are individuals who would like to learn novel things, enjoy new experiences and usually notch high in openness.

Conscientiousness:They are the ones with high degree of conscientiousness, reliability and promptness. They are organised and organized and thorough with almost everything.

* Expressive:These Individuals get their energy from interacting with others. They are energetic, talkative, and assertive.

* Sociableness: These individuals are friendly, cooperative, and compassionate. People with low agreeableness may be more distant. They are kind, affectionate, and sympathetic.

* Emotional Stability: This dimension relates to one's emotional stability and degree of negative emotions. Individuals who score low on emotional stability often experience emotional instability and negative emotions. They have mood swings and areoften tense".

\section{LITERATURE REVIEW}

Several studies have been conducted in the past to explore the impulsive buying behavior of consumers.

"Sofi and Nika (2017) investigated the influence of personality on impulsive buying behavior. The results reveal that personality has a significant impact on positive (affection) and negative (cognition) indicators of impulsive buying. All the determinants of personality significantly determine the personality of an individual and personality determines impulsive buying as both positive and negative indicators of impulsive buying are significant. Higher the degree of cognition, lower would be buying tendencies as its coefficient is negatively significant. Three attributes including expressive propensity, pleasure seeking propensity, and sociableness, are positive indicators of impulse buying tendencies, whereas conscientiousness, conserving propensity, and emotional instability are negative indicators of impulsiveness".

"Leela and Reddy (2015) explore the relationship between impulsive buying of and demographic variables of consumers in Hyderabad and Bangalore. The younger crowd shows a preference for promotional activities, trying new products and recent advertisements. Female consumers indicated a preference for low price products and discount offers. Male consumers tend to try new and innovative products. Occupation and income have a strong influence on impulsive buying behaviour".

"Bhatti and Latif (2013) researched regarding the association between impulse buying and visual merchandising on buying behavior of customers. The results suggested that window display, forum display, floor merchandising and shop brand name (independent variables) are significantly associated to consumer impulse buying behavior (dependent variable). Window display, floor merchandising and shop brand name are positively related impulse buying behavior of consumers whereas forum display is negatively related to consumer impulse buying".

"Lee and Kacen (2008) studied the impact of culture (individualist and collectivist consumers) and the presence of another person at the time of purchase on consumers' planned and impulse purchase decisions. They collected data from four countries (USA, Australia, Singapore and Malaysia) using a survey about a recent impulse and a recent planned purchase decision. The study used a 2 (purchase type: impulse versus planned) $\mathrm{X} 2$ (purchase situation: alone versus with an important other) X2 (cultural region: individualist versus collectivist) $\mathrm{X} 2$ (order: impulse first versus planned first) mixed factorial design and thus, four versions of 
questionnaires were formulated to collect data from 706 respondents about their recent impulse and planned purchase when they were with someone important or when they were alone. The results reveal that consumers from collectivist countries were more satisfied with their impulse purchase when they were with an important versus when they were alone at the time of purchase; whereas consumers from individualist countries showed no difference in satisfaction between these two purchase situations. The presence of another person influenced neither collectivists nor individualists for planned purchases".

"Bourlakis, Mamalis and Sangster (2005) studied the factors impacting unplanned buying that accounts for significant amount of supermarket purchases. They studied consumers who generally shop at a leading UK retailer. The results show that consumers are aware of the financial side of the shopping as three of the factors (value, price awareness and loyalty points) have a financial aspect to them. Respondents felt queuing time to be more important than loyalty points".

"Mai, Jung, Lantz and Loeb (2003)investigated the impulse buying behavior of urban consumers in Vietnam. Both qualitative and quantitative methods were used. They also identified personal-use and collective-use product categories. The research revealed that impulse purchases are more likely to happen with personal-use products than collective-use products. They used two models (impulse buying tendency and impulse buying frequency). The results show that individualist orientation was positively related to impulse buying but the study did not find the negative relationship between collectivist orientation and impulse buying to be significant. Regional differences did not really influence impulse buying. The study revealed a significant negative relationship between age and impulse buying in both models. The study also suggested a non-linear relationship between impulse buying and income levels. Qualitative study revealed that urban consumers in Vietnam indulge in small inexpensive impulsive purchases such as clothing, music items and gifts. This explains that economic transition in Vietnam has influenced consumers' attitudes, values and consumption behaviors. Thus, it explains the coexistence of individualism and collectivism in individuals. Men exhibited a higher impulse buying tendency then women".

"Kacen and Lee (2002) studied the influence of culture on consumer impulsive buying behavior through a survey of consumers in the United States, Australia, Hong Kong, Singapore and Malaysia. They carried out two studies to quantity the influence of culture on impulsive buying behavior of consumers. They hypothesized that consumers who are impulsive will indulge in more frequent impulsive purchases, but this relationship will become moderate in collectivist cultures. The survey was administered to 706 consumers in two individualistic countries (Australia and the United States) and two collectivist countries (Singapore and Malaysia). The results indicated a stronger relationship between trait buying impulsiveness and impulsive buying behavior for individualists compared to collectivists. The study suggested that culture moderates the impulse trait-behavior relationship. The results provide evidence that Asians engage in less impulse buying due to trait buying impulsiveness as compared to Caucasians. The findings reveal the consistent influence of culture at both ethnicity and individual level".

"Abratt and Goodey (1990)examined the occurrence of unplanned buying of non-food items in South Africa. The researchers did personal face-to-face interviews with shoppers at the entry point of the designated stores to form their buying intentions and at the exit point or check-out where actual purchases and reasons for selection weredocumented. The inconsistency between the actual purchases and the purchase intentions is then conceptualised to determine the level and nature of unplanned buying. Respondents purchased $22.5 \%$ of total non-food items as an unplanned purchase. The study reveals that $48 \%$ of the purchase decisions are made in store and $41 \%$ of the respondents spend more than their expressed spending intention".

\section{OBJECTIVES}

- To find the impact of culture on impulsive buying behaviour.

- To examine the relationship between personality traits and impulsive buying behaviour.

\section{DATA COLLECTION AND SAMPLING}

"To collect the data, convenience sampling technique has been used. The structured questionnaire/instruments consisting of sixty-six positive items were distributed to consumers from Delhi/NCR. The questionnaire included six demographic items (Gender, Age, Income, Occupation, Qualification and Income) and four major sections to measure the influence of culture (Individualism and Collectivism), personality (Sociableness, Pleasure Seeking Personality, Expressive, Conserving, Conscientiousness and Emotional Stability) on impulse buying behaviour( Impulse Buying Tendency and Impulse Buying Frequency). In closed ended items, five point Likert scale was used from 1-5: strongly disagree to strongly 
agree. The questionnaires were distributed to 258 consumers (168 online and 90 offline) and 232 responses (168 online and 64 offline) were received. Out of 232 responses, only 197 responses could be considered for analysis and remaining 35 were rejected due to missing data. For measuring individualism and collectivism, the scale used by Triandis and Gelfand(1998) was used whereas, for studying the influence of personality, the scale used was given by Sofi and Nika(2017)".

\section{HYPOTHESES}

- Impulse Buying Behavior is significantly related to Culture-Individualism

- Impulse Buying Behavior is significantly related to culture- Collectivism

- Impulse Buying Behavior is significantly related to Expressive Personality

- Impulse Buying Behavior is significantly related to Emotional Stability
- Impulse Buying Behavior is significantly related to Sociableness

- Impulse Buying Behavior is significantly related to Pleasure Seeking Propensity

- Impulse Buying Behavior is significantly related to Conserving Personality

- Frequency of buying moderates the relationship between personality traits and impulse buying behavior

- Frequency of buying moderates the relationship between culture and impulse buying behavior.

\section{Data Analysis}

1. Demographic Data: "Out of 197 respondents, 80 were males and 117 were females. 73 respondents were in the age group of 18-30 and 63 were in 31-40 and 40 were in 41-50 whereas 11 were in the age group of 51-60 and 10 were above 60 years".

2. Reliability Test: "To test reliability, Cronbach Alpha tool was applied through SPSS on 198 respondents' data. The Cronbach Alpha value was 0.916 which means the data is $91.6 \%$ reliable and can be used for further analysis".

\section{RESULTS AND CONCLUSION}

\section{Inter-correlation for all Variables}

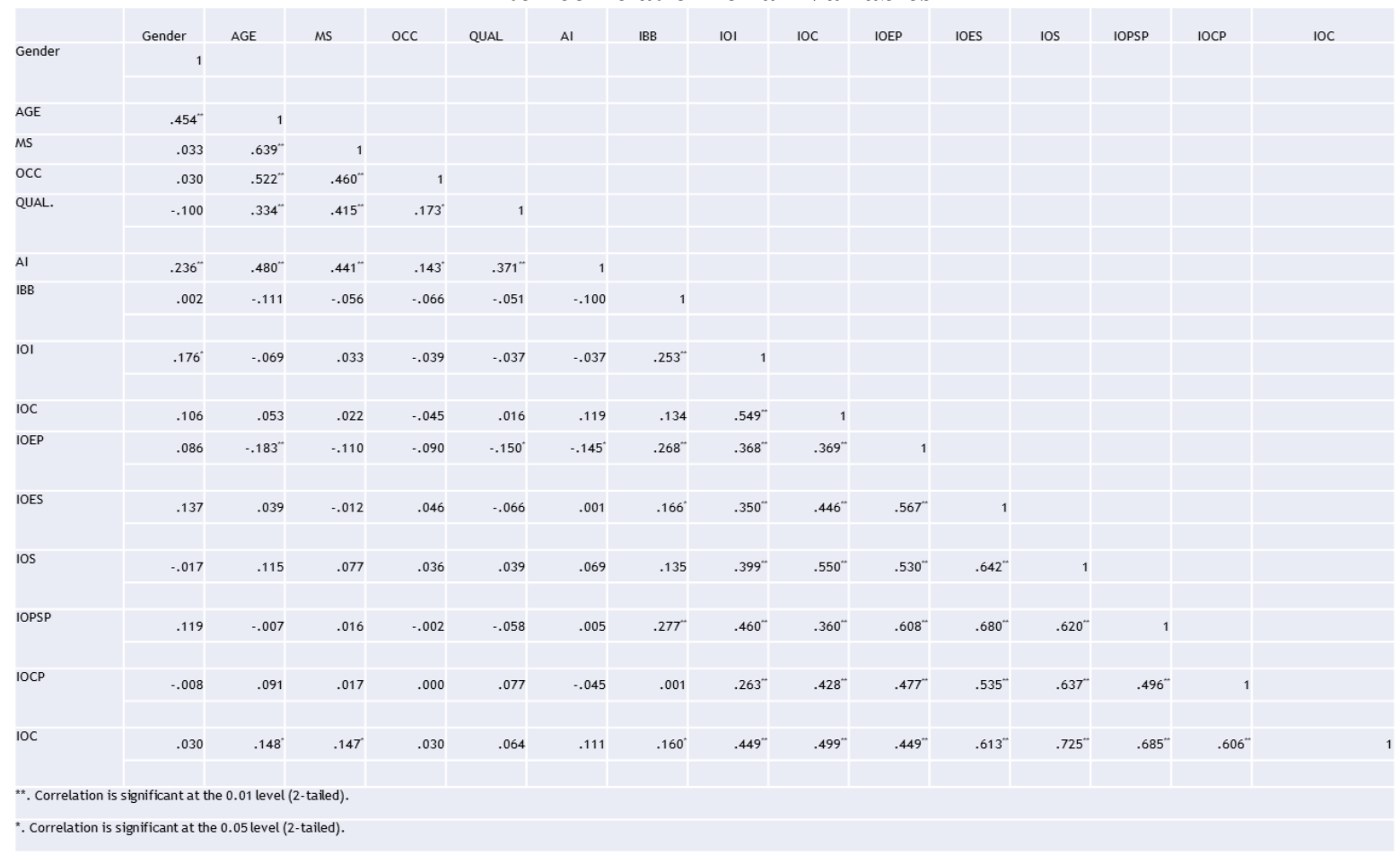

Hierarchical Regression

Hypothesis 1: Impulse Buying Behavior is significantly related to culture-Individualsim

Dependent Variable: Impulse Buying Behavior

\begin{tabular}{|l|l|l|l|l|l|}
\hline & $\begin{array}{l}\text { Independent } \\
\text { Variable }\end{array}$ & $\mathrm{B}$ & $\Delta \mathrm{R} 2$ & $\mathrm{R} 2$ & $\mathrm{~N}$ \\
\hline \multirow{3}{*}{$\begin{array}{l}\text { Step } \\
1\end{array}$} & Age & -0.20 & & 0.015 & \\
\cline { 2 - 4 } \cline { 6 - 6 } & Gender & -0.31 & & & \\
\cline { 2 - 4 } & Marital Status & 0.07 & & & \\
\cline { 2 - 4 } & Occupation & -0.13 & & & \\
\hline
\end{tabular}

\begin{tabular}{|c|c|c|c|c|c|}
\hline & $\begin{array}{l}\text { Qualification } \\
\text { Annual } \\
\text { Income }\end{array}$ & $\begin{array}{l}-0.06 \\
-0.026\end{array}$ & & & \\
\hline $\begin{array}{l}\text { Step } \\
2\end{array}$ & Individualism & $0.255^{* *}$ & 0.058 & 0.073 & 197 \\
\hline
\end{tabular}

Note: Betas are for the last step reported. “* $\mathbf{p}<0.05, * * \mathbf{p}<0.01, * * * \mathbf{p}<0.001 "$ 
Hypothesis 2: Impulse Buying Behavior is significantly related to culture-Collectivism

Dependent Variable: Impulse Buying Behavior

\begin{tabular}{|c|c|c|c|c|c|}
\hline-1 & $\begin{array}{l}\text { Independent } \\
\text { Variable }\end{array}$ & $\mathrm{B}$ & $\Delta \mathrm{R} 2$ & $\mathrm{R} 2$ & $\mathrm{~N}$ \\
\hline \multirow[t]{4}{*}{ Step 1} & Age & -0.043 & & \multirow[t]{4}{*}{.015} & \\
\hline & Gender & 0.017 & & & \\
\hline & $\begin{array}{l}\text { Marital } \\
\text { Status }\end{array}$ & 0.057 & & & \\
\hline & $\begin{array}{l}\text { Occupation } \\
\text { Qualification } \\
\text { Annual } \\
\text { Income }\end{array}$ & $\begin{array}{l}-0.012 \\
-0.005 \\
-0.043\end{array}$ & & & \\
\hline Step 2 & Collectivism & 0.140 & 0.20 & 0.34 & 197 \\
\hline
\end{tabular}

Note: Betas are for the last step reported.

${ }^{6 *} \mathbf{p}<0.05, * * \mathbf{p}<0.01, * * * \mathbf{p}<0.001 "$

Hypothesis 3: Impulse Buying Behavior is significantly related to Expressive Personality

Dependent Variable: Impulse Buying Behavior

\begin{tabular}{|c|c|c|c|c|c|}
\hline & $\begin{array}{l}\text { Independent } \\
\text { Variable }\end{array}$ & B & $\Delta \mathrm{R} 2$ & $\mathrm{R} 2$ & $\mathrm{~N}$ \\
\hline \multirow{4}{*}{$\begin{array}{l}\text { Step } \\
1\end{array}$} & Age & -0.014 & & \multirow[t]{4}{*}{0.015} & \\
\hline & Gender & -0.008 & & & \\
\hline & $\begin{array}{l}\text { Marital } \\
\text { Status }\end{array}$ & 0.033 & & & \\
\hline & $\begin{array}{l}\text { Occupation } \\
\text { Qualification } \\
\text { Annual } \\
\text { Income }\end{array}$ & $\begin{array}{r}-0.017 \\
0.006 \\
-0.025\end{array}$ & & & \\
\hline $\begin{array}{l}\text { Step } \\
2\end{array}$ & $\begin{array}{l}\text { Expressive } \\
\text { Personality }\end{array}$ & $0.220 * * *$ & 0.62 & 0.77 & 197 \\
\hline
\end{tabular}

Note: Betas are for the last step reported.

"*p $<0.05, * * \mathbf{p}<0.01, * * * \mathbf{p}<0.001 "$

Hypothesis 4: Impulse Buying Behavior is significantly related to Emotional Stability

Dependent Variable: Impulse Buying Behavior

\begin{tabular}{|l|l|l|l|l|l|}
\hline \multirow{2}{*}{$\begin{array}{l}\text { Step } \\
1\end{array}$} & $\begin{array}{l}\text { Independent } \\
\text { Variable }\end{array}$ & $\mathrm{B}$ & $\Delta \mathrm{R} 2$ & $\mathrm{R} 2$ & $\mathrm{~N}$ \\
& Age & -0.047 & & 0.015 & \\
\cline { 2 - 4 } & Gender & 0.007 & & & \\
\cline { 2 - 4 } & Marital & 0.064 & & & \\
& Status & & & & \\
\cline { 2 - 4 } & Occupation & -0.019 & & & \\
& Qualification & 0.001 & & & \\
& Annual & & & & \\
\hline \multirow{2}{*}{$\begin{array}{l}\text { Step } 2 \\
2\end{array}$} & Income & -0.035 & & & \\
\hline
\end{tabular}

Note: Betas are for the last step reported.

${ }^{6 *} \mathbf{p}<0.05, * * \mathbf{p}<0.01, * * * \mathbf{p}<0.001 "$
Hypothesis 5: Impulse Buying Behavior is significantly related to Sociableness

Dependent Variable: Impulse Buying Behavior

\begin{tabular}{|c|c|c|c|c|c|}
\hline & $\begin{array}{l}\text { Independent } \\
\text { Variable }\end{array}$ & B & $\Delta \mathrm{R} 2$ & R2 & $\mathrm{N}$ \\
\hline \multirow[t]{4}{*}{ Step 1} & Age & 0.087 & & \multirow[t]{4}{*}{0.015} & \\
\hline & Gender & 0.486 & & & \\
\hline & $\begin{array}{l}\text { Marital } \\
\text { Status }\end{array}$ & 0.232 & & & \\
\hline & $\begin{array}{l}\text { Occupation } \\
\text { Qualification } \\
\text { Annual } \\
\text { Income }\end{array}$ & $\begin{array}{l}0.171 \\
0.236 \\
0.096 \\
\end{array}$ & & & \\
\hline Step 2 & Sociableness & 0.041 & 0.20 & 0.035 & 197 \\
\hline
\end{tabular}

Note: Betas are for the last step reported.

“*p $<0.05, * * \mathbf{p}<0.01, * * * \mathbf{p}<0.001 "$

Hypothesis 6: Impulse Buying Behavior is significantly related to Pleasure Seeking Persoanlity

Dependent Variable: Impulse Buying Behavior

\begin{tabular}{|c|c|c|c|c|c|}
\hline & $\begin{array}{l}\text { Independent } \\
\text { Variable }\end{array}$ & $\mathrm{B}$ & $\Delta \mathrm{R} 2$ & $\mathrm{R} 2$ & $\mathrm{~N}$ \\
\hline \multirow{4}{*}{$\begin{array}{l}\text { Step } \\
1\end{array}$} & Age & -0.037 & & \multirow[t]{4}{*}{0.015} & \\
\hline & Gender & -0.006 & & & \\
\hline & $\begin{array}{l}\text { Marital } \\
\text { Status }\end{array}$ & 0.036 & & & \\
\hline & $\begin{array}{l}\text { Occupation } \\
\text { Qualification } \\
\text { Annual } \\
\text { Income }\end{array}$ & $\begin{array}{r}-0.015 \\
0.005 \\
-0.035\end{array}$ & & & \\
\hline $\begin{array}{l}\text { Step } \\
2\end{array}$ & $\begin{array}{l}\text { Pleasure } \\
\text { Seeking } \\
\text { Propensity }\end{array}$ & $0.249 * * *$ & 0.073 & 0.088 & 197 \\
\hline
\end{tabular}

Note: Betas are for the last step reported.

"* $\mathbf{p}<0.05, * * \mathbf{p}<0.01, * * * \mathbf{p}<0.001 "$

Hypothesis 7: Impulse Buying Behavior is significantly related to Conserving Personaliy

Dependent Variable: Impulse Buying Behavior

\begin{tabular}{|c|c|c|c|c|c|}
\hline & $\begin{array}{l}\text { Independent } \\
\text { Variable }\end{array}$ & B & $\Delta \mathrm{R} 2$ & $\mathrm{R} 2$ & $\mathrm{~N}$ \\
\hline \multirow{4}{*}{$\begin{array}{l}\text { Step } \\
1\end{array}$} & Age & -0.037 & & \multirow[t]{4}{*}{0.015} & \\
\hline & Gender & 0.028 & & & \\
\hline & $\begin{array}{l}\text { Marital } \\
\text { Status }\end{array}$ & 0.053 & & & \\
\hline & $\begin{array}{l}\text { Occupation } \\
\text { Qualification } \\
\text { Annual } \\
\text { Income }\end{array}$ & $\begin{array}{l}-0.018 \\
-0.007 \\
-0.036\end{array}$ & & & \\
\hline $\begin{array}{l}\text { Step } \\
2\end{array}$ & $\begin{array}{l}\text { Conserving } \\
\text { Personality }\end{array}$ & -0.001 & 0.000 & 0.015 & 197 \\
\hline
\end{tabular}

Note: Betas are for the last step reported.

${ }^{6 *} \mathbf{p}<0.05, * * \mathbf{p}<0.01, * * * \mathbf{p}<0.001 "$ 
Culture and Personality: A Examination of Impulsive Buying Behavior of Indian Consumers

Dependent Variable: Impulse Buying Behavior

\begin{tabular}{|c|c|c|c|c|}
\hline & & \multicolumn{3}{|c|}{ Impulse Buying Behavior } \\
\hline & $\begin{array}{c}\text { Independent } \\
\text { Variable }\end{array}$ & B & $\mathrm{R}$ & R2 \\
\hline $\begin{array}{l}\text { Without } \\
\text { moderation }\end{array}$ & Individualism & $0.261 * * *$ & 0.253 & 0.064 \\
\hline Moderation & $\begin{array}{l}\text { Individualism with } \\
\text { Frequency of } \\
\text { Impulse Buying }\end{array}$ & $0.248 * * *$ & 0.445 & 0.198 \\
\hline
\end{tabular}

Dependent Variable: Impulse Buying Behavior

\begin{tabular}{|c|c|c|c|c|}
\hline & & \multicolumn{3}{|c|}{ Impulse Buying Behavior } \\
\hline & $\begin{array}{c}\text { Independent } \\
\text { Variable }\end{array}$ & B & $\mathrm{R}$ & $\mathrm{R} 2$ \\
\hline $\begin{array}{c}\text { Without } \\
\text { moderation }\end{array}$ & Collectivism & 0.132 & 0.134 & 0.018 \\
\hline Moderation & $\begin{array}{l}\text { Collectivism with } \\
\text { Frequency of } \\
\text { Impulse Buying }\end{array}$ & $0.143 *$ & 0.401 & 0.161 \\
\hline
\end{tabular}

Dependent Variable: Impulse Buying Behavior

\begin{tabular}{|c|c|c|c|c|}
\hline & & \multicolumn{3}{|c|}{ Impulse Buying Behavior } \\
\hline & $\begin{array}{c}\text { Independent } \\
\text { Variable }\end{array}$ & $\mathrm{B}$ & $\mathrm{R}$ & $\mathrm{R} 2$ \\
\hline $\begin{array}{c}\text { Without } \\
\text { moderation }\end{array}$ & $\begin{array}{l}\text { Expressive } \\
\text { Personality }\end{array}$ & $0.231 * * *$ & 0.268 & 0.072 \\
\hline Moderation & $\begin{array}{c}\text { Expressive } \\
\text { Personality with } \\
\text { Frequency of } \\
\text { Impulse Buying }\end{array}$ & $0.241 * * *$ & 0.467 & 0.218 \\
\hline
\end{tabular}

Dependent Variable: Impulse Buying Behavior

\begin{tabular}{|c|c|c|c|c|}
\hline & & \multicolumn{3}{|c|}{ Impulse Buying Behavior } \\
\hline & $\begin{array}{l}\text { Independent } \\
\text { Variable }\end{array}$ & $\mathrm{B}$ & $\mathrm{R}$ & $\mathrm{R} 2$ \\
\hline $\begin{array}{c}\text { Without } \\
\text { moderation }\end{array}$ & Emotional Stability & $0.144 *$ & 0.166 & 0.028 \\
\hline Moderation & $\begin{array}{c}\text { Emotional Stability } \\
\text { wuth Frequency of } \\
\text { Impulse Buying }\end{array}$ & $0.166^{* *}$ & 0.420 & 0.177 \\
\hline
\end{tabular}

$$
\mathbf{N}=197
$$




\section{Dependent Variable: Impulse Buying Behavior}

\begin{tabular}{|c|c|c|c|c|}
\hline & & \multicolumn{3}{|c|}{ Impulse Buying Behavior } \\
\hline & $\begin{array}{c}\text { Independent } \\
\text { Variable }\end{array}$ & $\mathrm{B}$ & $\mathrm{R}$ & $\mathrm{R} 2$ \\
\hline $\begin{array}{c}\text { Without } \\
\text { moderation }\end{array}$ & Sociableness & 0.139 & 0.135 & 0.018 \\
\hline Moderation & $\begin{array}{c}\text { Sociableness with } \\
\text { Frequency of } \\
\text { Impulse Buying }\end{array}$ & $0.147 *$ & 0.401 & 0.161 \\
\hline \multicolumn{3}{|c|}{} & & \\
\hline
\end{tabular}

"* $\mathbf{p}<0.05, * * p<0.01, * * * p<0.001 "$

$$
\mathbf{N}=197
$$

Dependent Variable: Impulse Buying Behavior

\begin{tabular}{|c|c|c|c|c|}
\hline & & \multicolumn{3}{|c|}{ Impulse Buying Behavior } \\
\hline & $\begin{array}{c}\text { Independent } \\
\text { Variable }\end{array}$ & $\mathrm{B}$ & $\mathrm{R}$ & R2 \\
\hline $\begin{array}{c}\text { Without } \\
\text { moderation }\end{array}$ & $\begin{array}{c}\text { Pleasure Seeking } \\
\text { Personality }\end{array}$ & $0.252 * * *$ & 0.277 & 0.077 \\
\hline Moderation & $\begin{array}{l}\text { Pleasure Seeking } \\
\text { Personality with } \\
\text { Frequency of } \\
\text { Impulse Buying }\end{array}$ & $0.250 * * *$ & 0.465 & 0.216 \\
\hline
\end{tabular}

Dependent Variable: Impulse Buying Behavior

\begin{tabular}{|c|c|c|c|c|}
\hline & & \multicolumn{3}{|c|}{ Impulse Buying Behavior } \\
\hline & $\begin{array}{c}\text { Independent } \\
\text { Variable }\end{array}$ & $\mathrm{B}$ & $\mathrm{R}$ & $\mathrm{R} 2$ \\
\hline $\begin{array}{c}\text { Without } \\
\text { moderation }\end{array}$ & $\begin{array}{c}\text { Conserving } \\
\text { Personality }\end{array}$ & 0.001 & 0.001 & 0.000 \\
\hline Moderation & $\begin{array}{c}\text { Conserving } \\
\text { Personality with } \\
\text { Frequency of } \\
\text { Impulse Buying }\end{array}$ & 0.05 & 0.379 & 0.143 \\
\hline
\end{tabular}

“* $\mathbf{p}<0.05, * * \mathbf{p}<0.01, * * * \mathbf{p}<0.001 "$

$$
\mathrm{N}=197
$$

Results

- Hypothesis 1: Accepted at 1\% level of significance.

- Hypothesis 2: Rejected

- Hypothesis 3: Accepted at 1\% level of significance.

- Hypothesis 4: Accepted at 5\% level of significance.

- Hypothesis 5: Rejected

- Hypothesis 6: Accepted at 1\% level of significance.

- Hypothesis 7: Rejected

"Consumers who are expressive and have pleasure seeking propensity, ensure a higher tendency to buy things on impulse. Thus, sellers should identify highly expressive consumers and consumers with pleasure seeking personality and attract them through different color combinations to amplify the expressiveness and pleasure-seeking propensity of consumers whereas other personality attributes like emotional stability, conscientiousness and conserving propensity should be spoiled through various promotional strategies".

\section{CONCLUSIONS AND LIMITATIONS}

"The sample was physically limited because the data was primarily collected from Delhi/NCR. Thus, the data collected from different areas may yield varied results. Only quantitative research method (questionnaire) was used, but the qualitative research methods may fetch different outcomes".

\section{REFERENCES}

1. Abratt, R., Goodey, S.D.,'Unplanned Buying and In-store Stimuli in Supermarkets", Managerial and Decision Economics, Vol. 11, No.2(May 1990), p. 111-121.

3. Bourlakis, M.,Mamalis,S, Sangster, J., "Planned versus Unplanned Grocery Shopping: An Empirical Study", Proceedings of the $5^{\text {th }}$ WSEAS International Conference on Distance Learning and Web Engineering, Greece, August, 2005.

4. Engel, James F. David T.Kollat, and Roger D.Blackwell(1978), “ Consumer Behavior", Hinsdale, IL: Dryden Press. 
5. Francis Piron (1933), "A Comparison of Emotional Reactions Experienced by Planned, Unplanned and Impulse Purchasers", in NA-Advances in Consumer Research, Volume 20. Eds, Leigh McAlister and Michael L. Rothschild, Provo, UT: Association for Consumer Research.

6. Haq, Mirza A., Abbasi, Sakman, "Indirect Impact of Hedonic Consumption and Emotions on Impulse Purchase Behavior: A Double Mediation Model", Journal of Management Sciences, Vol. 3(2),108-112,2016

7. Kaur, Amandeep, Megha, "Factor Influencing Unplanned Buying Behavior of Untapped Market", IOSR Journal of Business and Management, Special Issue-AETM'16.

8. Kacen, Jacqueline J., Lee, Julie A.,"The Influence of Culture on Consumer Impulsive Buying", Journal of Consumer Psychology, 12(2), 163-176.

9. Kollat, David T., Willet Ronald P., "Customer Impulse Purchasing Behavior", Journal of Marketing Research, Vol.4, No.1 (Feb.,1967), pp. 21-31.

10. Lee, Julie A. and Kacen, Jacqueline J.(2000), "The Relationship between Independent and Interdependent Self-Concepts and Reasons for Purchase," Cross-national Consumer Psychographics, the Hworth Press, 83-99.

1. 16. Lee, Julie A., Kacen, Jacqueline J.,’Cultural Influences on Consumer Satisfaction with Impulse and Planned Purchase Decisions", Journal of Business Research, 61(2008),265-272.

11. Leela, Hari V., Reddy, P. Narayana, "Impulsive Buying Behavior Tendencies in Developing Markets: With Special Reference to Demographic Characteristics of Consumers (A Preliminary Study)", International Journal of Engineering Technology, Management and Applied Sciences, September, 2015, Volume 3, Special Issue.

12. Mai,N.T.T.,Jung K., Lantz,G., Loeb, Sandra, G., “An Exploratory Investigation into Impulsive Buying Behavior in a Transitional Economy: A Study of Urban Consumers in Vietnam", Journal of International Marketing, Volume 11, Issue 3(Summer 2003).

13. Park, EJ., Kim, EY, "Effect of Consumer Tendencies and Postive Emotions on Impulse Buying Behavior for Apparel", Journal of Korean Soc Clothing Textiles, 2008, 32(6), 980-990.

14. Pirom, Francis (1990), "Defining Impulse Purchases," in Advances in Consumer Research, Vol.18, eds. Rebecca H. Holman and Michae R.Solomon, Provo, UT.: Association for Consumer Research, 509-514.

15. Ramankutty, Sumesh, Babu, Deepak, Venugopal, Balu, "Value of Seconds- Impulse Buying Behavior and its Antecedents", Abhinav International Monthly Refreed Journal of Research in Management and Technology, Vol.3, No.3, 2014.

16. Shahjehan, AsadJaweriaAndleebQureshi, Zeb, Faheem, Sifullah, Kaleem,"The Effect of Personality on Impulsive and Compulsive Buying", African Journal of Business Management, Vol.6(6), pp 2187-2194, $15^{\text {th }}$ February,2012.

17. Sofi, Shakeel Ahmad, Nika, FayazAhmad,"The Role of Personality in Impulse Buying Behavior", Jindal Journal of Business Research, 5(1)26-50, OP Jindal Global University, Sage Publications, 2017.

18. Tinne, WahidaShahan, "Factors Affecting Impulse Buying Behavior of Consumers at Superstores in Bangladesh", ASS University Review, Vol.5, No.1, January-June,2011,209-218.

19. Triandis, H.C.(1994), Culture and Social Behavior, New York, Mc-Graw Hill.

20. Triandis, H.C.(1995), Individualism and Collectivism, Boulder, CO, Westview Press.

21. Verplanken, Bas, Herabadi, Astrid,'Individual Differences in Buying Buying Tendency: Feeling and No Thinking", European Journal of Personlity,15:S71-S83,(2001). 